Огляди літератури, оригінальні дослідження, погляд на проблему, випадок з практики, короткі повідомлення УДК 616.98:579.834.114-085.322:582.998.1.063

DOI 10.11603/1811-2471.2020.v.i1.11087

\title{
ПІДВИЩЕННЯ ЕФЕКТИВНОСТІ КОМПЛЕКСНОГО ЛІКУВАННЯ ХВОРИХ НА ЛАЙМ-БОРЕЛІОЗ ІЗ ВИКОРИСТАННЯМ СТЕВІЇ МЕДОНОСНОЇ
}

\author{
๑М. І. Шкільна, С. М. Марчишин, М. А. Андрейчин, О. Л. Івахів, \\ М. М. Корда, С. Й. Запорожан, І. М. Кліщ
}

\author{
Тернопільський національний медичний університет імені І. Я. Горбачевського Моз України
}

РЕЗЮМЕ. Мета - удосконалення комплексного лікування хворих на Лайм-бореліоз (ЛБ) за допомогою поєднаного застосування доксицикліну гідрохлориду та настою з листків стевії медоносної.

Матеріал і методи. Під спостереженням було 113 хворих із еритемною формою Лайм-бореліозу; чоловіків49 (43,4 \%), жінок - 64 (56,6 \%). Середній вік обстежених склав $(42,65 \pm 13,91)$ року. Апробовано дві схеми комплексного лікування хворих. Пацієнти 1-ї групи (53) отримували доксицикліну гідрохлорид по 200 мг в день (у 2 прийоми по 100 мг) протягом 21 дня, карсил і хілак; хворі 2-ї групи (60) - першу схему впродовж 14 днів, а далі - настій 3 листків стевії медоносної (Stevia rebaudiana (Bertoni) Hemsley) по 1 склянці двічі на день протягом 14 днів.

Результати. У хворих, які у комплексному лікуванні отримували доксицикліну гідрохлорид разом із настоєм із листків стевії медоносної, на 30-й день після закінчення лікування відзначено достовірно менший ступінь тяжкості ЛБ, порівняно з особами іншої групи.

Комплексна терапія пацієнтів з використанням настою із листків стевії медоносної зумовлює зменшення вмісту в сироватці крові прозапального ІЛ-18 і підвищення концентрації протизапального ІЛ-10.

Висновки. Комплексне лікування хворих на еритемну форму Лайм-бореліозу з використанням настою із листків стевії медоносної сприяє суттєво швидшому зникненню клінічних проявив недуги, скороченню термінів призначення доксицикліну гідрохлориду, а також зменшує ймовірність виникнення побічних ефектів від цього препарату.

Застосування в комплексному лікуванні хворих на еритемну форму хвороби Лайма доксицикліну гідрохлориду разом з настоєм із листків стевії медоносної забезпечує ранню протизапальну реакцію, формування клітинного і гуморального імунітенту, що сприяє елімінації борелій та одужанню хворого.

КЛючОВІ СлОВА: Лайм-бореліоз; доксицикліну гідрохлорид; стевія медоносна; лікування.

Вступ. Хвороба Лайма (ХЛ) - мультисистемне трансмісивне захворювання, спричинене Borrelia burgdorferi [1]. Лише у США щорічно реєструють близько 300000 випадків недуги, в Європі - до 65000 [2].

Загальноприйнятої схеми лікування хворих з цією недугою на сьогодні не розроблено. Однак для запобігання хронізації хвороби і виникненню несприятливих наслідків суттєве значення має рання адекватна протимікробна терапія [3].

Встановлено, що провідною ланкою в патогенезі бореліозної інфекції $є$ патогенна дія збудників у поєднанні з характером системної імунної відповіді макроорганізму [4-6]. Факторами вірулентності B. burgdorferiє поверхневі Osp-білки (ліпопротеїни зовнішньої мембрани клітинної стінки). Вони активують макрофаги, дендритні клітини, Т- і В-лімфоцити, які виділяють особливі речовини білкової природи - цитокіни, що здійснюють короткодистантну регуляцію міжклітинних взаємодій [7].

Для етіотропної терапії ХЛ здебільшого використовують антибіотики трьох фармакологічних груп: тетрацикліни, цефалоспорини і макроліди [3]. Вибір антибіотика, його доза та тривалість застосування залежать від клінічної форми і стадії захворювання, а також тяжкості перебігу недуги
[8]. Препаратом вибору натепер $є$ доксициклін антибіотик широкого спектра дії з класу тетрациклінів із вираженою антибактерійною та антипаразитною дією [9]. Хоча доксициклін є одним із найбільш вживаних препаратів, особливо на ранніх стадіях ХЛ, його тривале застосування не доцільне, оскільки ефективність такого призначення не доведена [10], а ймовірність виникнення численних побічних явищ значно зростає.

Відомо, що рослини, їх екстракти та метаболіти $\epsilon$ цінними джерелом природних сполук, які ефективні щодо збудників різних інфекцій, у тому числі й Лайм-бореліозу [11]. У літературі $є$ окремі повідомлення щодо спроб лікування ХЛ антимікробними ліками у поєднанні з фітопрепаратами [11].

Однією з таких рослин, яка сьогодні знайшла широке застосування у медичній практиці при лікуванні багатьох захворювань, є стевія медоносна (Stevia rebaudiana (Bertoni) Hemsley). Це багаторічна трав'яниста рослина, яка в дикому вигляді зустрічається лише в Парагваї та Південній Бразилії. Культивується в Парагваї, Японії, США, Ізраїлі, Аргентині, на півдні України [12]. Листки стевії містять значну кількість стевіозилів і ребаудіозидів, завдяки яким вони у 300 разів солодші за цукор [13] і застосовуються як його замінник при цукровому діабеті та ожирінні [14]. Водночас $\epsilon$ 
Огляди літератури, оригінальні дослідження, погляд на проблему, випадок з практики, короткі повідомлення ряд досліджень, які демонструють, що стевіозид має протимікробну дію проти Bacillus cereus, Bacillus subtilis, Klebsiella pneumoniae та Pseudomonas aeruginosa [15]. Виражений вплив мають біологічно активні речовини (БАР) стевії медоносної також на Pantoea agglomerans, Myxococcus sp., Staphylococcus sp., Fusarium solani, Aspergillus terreus [16].

Науковцями ТНМУ імені І. Я. Горбачевського встановлено, що листки стевії містять органічні сполуки та аскорбінову кислоту (4,95 \% і 0,17\%, відповідно), фенольні сполуки (6,67 \% гідроксикоричних кислот, 1,23 \% флавоноїдів, 5,38 \% поліфенолів) тощо $[17,18]$.

3 джерел літератури відомо, що фенольні сполуки забезпечують антиоксидантну і протизапальну дію стевії [17]. Комплекс БАР цієї рослини позитивно впливає на всі життєво важливі системи організму людини: підвищує опірність організму до інфекційних захворювань, нормалізує рівень цукру в крові, є природним антиоксидантом [19].

Мета - удосконалення комплексного лікування хворих на Лайм-бореліоз за допомогою поєднаного застосування доксицикліну гідрохлориду та настою з листків стевії медоносної.

Матеріал і методи дослідження. Під спостереженням було 113 осіб віком від 18 до 70 років, хворих на еритемну форму ЛБ, які перебували на амбулаторному і стаціонарному лікуванні в КУ ТОР «Тернопільський обласний клінічний шкірно-венерологічний диспансер» та інфекційному відділенні КНП «Тернопільська міська комунальна лікарня швидкої допомоги» протягом 2017-2019 рр. Чоловіків було 49 (43,4 \%), жінок - 64 (56,6 \%). Середній вік обстежених склав $(42,65 \pm 13,91)$ року.

Діагноз кільцеподібної мігруючої еритеми (ME) встановлювали клінічно на підставі характерних проявів і даних епідеміологічного анамнезу (перебування в ендемічній зоні щодо ЛБ, вказівка на присмоктування кліща).

Усі пацієнти мали гострий перебіг захворювання, відповідно до клінічних класифікацій Ю. В. Лобзіна і співавт. (2000), А. С. Свінціцького (2012) [3].

Апробовано дві схеми комплексного лікування хворих із еритемною формою ЛБ, згідно з якими усіх пацієнтів поділили на дві групи. Хворі 1-ї групи (53) отримували доксицикліну гідрохлорид по 200 мг у день (у 2 прийоми по 100 мг) протягом 21 дня, карсил і хілак у середньотерапевтичних дозах. У пацієнтів 2-ї групи (60) зазначену схему лікування застосовували впродовж 14 днів з наступним призначенням настою з листків стевії медоносної по 1 склянці двічі на день протягом 14 днів.

Ефективність апробованих схем оцінювали за динамікою клінічних проявів хвороби і рівнів цитокінів у сироватці крові пацієнтів: прозапального інтерлейкіну (ІЛ) 18 [20] та протизапального ІЛ-10. ІЛ визначали двічі - до лікування та після його закінчення через 30 днів.

Тяжкість патологічного процесу оцінювали у балах: кожний симптом недуги оцінювали в 1 бал, а потім підраховували суму. На початку дослідження усі пацієнти отримали один бал за наявність первинного афекту шкіри у вигляді ME, далі додавали по 1 балу за наявність кожного з симптомів ураження інших органів і систем організму при лБ. Ступінь тяжкості недуги за сумою балів вважали таким: від 1 до 3 балів - легкий; від 3 до 6 - середньої тяжкості; понад 7 балів - тяжкий ступінь.

Концентрацію ІЛ-10 та ІЛ-18 визначали в сироватці крові пацієнтів методом ІФА з використанням тест-систем виробництва ЗАТ «ВекторБест». Референтними значеннями були такі концентрації цитокінів: для ІЛ-10 - до 31 пг/мл; для ІЛ-18 - від 104 до 650 пг/мл.

Статистичне опрацювання отриманих результатів проводили з використанням методів параметричної та непараметричної статистики за допомогою комп'ютерних програм «Mісгоsoft Office Excel» i «Statistica».

Для кількісних даних з правильним розподілом розраховували середнє значення (Mean (M)) \pm стандартне відхилення (SD); для кількісних даних з неправильним розподілом - медіану (Me) і нижній (Lq) та верхній (Uq) квартилі; для якісних показників - абсолютну (п) і відносну (\%) кількість та 95 \% довірчий інтервал (95\% ДІ).

Усі клінічні та лабораторні дані обробляли методами варіаційної статистики з оцінкою достовірності відмінностей між показниками, що порівнювали. При порівнянні правильно розподілених величин використовували критерій Стьюдента.

Результати й обговорення. На три і більше нападів кліщів протягом життя вказали 46 (40,7 \%) пацієнтів із 113 обстежених з ЛБ, два епізоди мали 11 (9,7 \%), один - 30 (26,6 \%) респондентів. Слід зазначити, що 26 (23,0 \%) осіб не пам'ятали епізоду нападу кліщів, проте появу МЕ пов'язували із відвідуванням лісу, присадибних ділянок або міських парків (табл. 1).

Ступінь тяжкості патологічного процесу при ХЛ у пацієнтів обох груп визначали тричі: у день звертання (до початку лікування), на 10-ий і на 30-ий дні після закінчення лікування.

За ступенем тяжкості патологічного процесу, вираженим у балах, до лікування групи хворих суттєво не відрізнялись ( $>0,05)$ (табл. 2). Під впливом терапії на 10-й день відзначено тенденцію до зменшення тяжкості перебігу недуги в обох групах пацієнтів, на 30-ий день ступінь тяжкості ЛБ знизився суттєво. Так, тяжкість патологічного процесу за сумою балів в осіб 1-ї групи до лікування склала 
Огляди літератури, оригінальні дослідження, погляд на проблему, випадок з практики, короткі повідомлення

Таблиця 1. Частота нападів кліщів на хворих із еритемною формою Лайм-бореліозу, поєднану з ураженнями інших органів і систем ( $n=113 ;$ Me (Lq; Uq)

\begin{tabular}{|l|c|c|c|}
\hline Кількість нападів кліщів & $\begin{array}{c}\text { Постраждалі } \\
\text { особи, } n\end{array}$ & $\begin{array}{c}\text { Відсоток } \\
\text { постраждалих }\end{array}$ & $\begin{array}{c}\text { Довірчий інтервал } \\
(95 \% \text { ДІ) }\end{array}$ \\
\hline Один & 30 & 26,6 & 18,$41 ; 34,69$ \\
\hline Два & 11 & 9,7 & 4,$27 ; 15,19$ \\
\hline Три і більше & 46 & 40,7 & 31,$65 ; 49,77$ \\
\hline $\begin{array}{l}\text { Не мали жодного або не } \\
\text { пам'ятають }\end{array}$ & 26 & 23,0 & 13,$70 ; 28,78$ \\
\hline
\end{tabular}

Таблиця 2. Динаміка тяжкості патологічного процесу у хворих на еритемну форму Лайм-бореліозу,

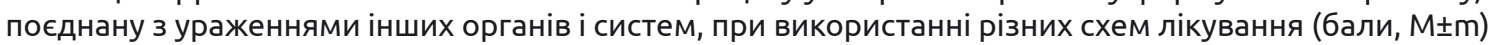

\begin{tabular}{|c|c|c|c|}
\hline \multirow{2}{*}{ Група пацієнтів } & \multicolumn{3}{|c|}{ Бали у дні до і після лікування } \\
\hline & до лікування & 10-ий день після лікування & 30-ий день після лікування \\
\hline 1-a $(n=53)$ & $4,37 \pm 0,42$ & $3,68 \pm 0,52$ & $1,25 \pm 0,43^{*}$ \\
\hline 2-a $(n=60)$ & $4,06 \pm 0,40$ & $2,46 \pm 0,37$ & $0,26 \pm 0,15^{*, * *}$ \\
\hline
\end{tabular}

Примітки: * - різниця достовірна з показниками до лікування $(p<0,05)$,

** - різниця достовірна з показниками 1-ї групи $(p<0,05)$.

$(4,37 \pm 0,42)$ бала, а на час його закінчення вона становила $(1,25 \pm 0,43)$ бала $(p<0,05)$, в осіб 2-ї групи відповідно $(4,06 \pm 0,40)$ і $(0,26 \pm 0,15)$ бала $(p<0,05)$. Окрім того, на 30-ий день від початку лікування в пацієнтів 2-ї групи ступінь тяжкості, виражений у балах, був суттєво меншим, ніж в осіб 1-ї, яка отримувала етіотропну терапію лише доксицикліну гідрохлоридом.

Отже, у хворих, які у комплексному лікуванні отримували настій з листків стевії медоносної, на 30-ий день після закінчення лікування відзначено достовірно менший ступінь тяжкості ЛБ, ніж в осіб іншої групи.
При дослідженні змін вмісту прозапального ІЛ-18 у сироватці крові обстежених пацієнтів з МЕ, які отримували різне лікування, встановлено таке: до призначення терапії рівень цього цитокіну в пацієнтів обох груп суттєво не відрізнявся $(p>0,05)$ і був у межах фізіологічної норми (табл. 3). У хворих 1-ї групи після завершення лікування концентрація ІЛ-18 достовірно не відрізнялась від початкової (р>0,05), натомість в осіб, яких лікували з використанням настою з листків стевії медоносної, рівень цього ІЛ суттєво зменшувався, хоча й залишався у межах норми.

Таблиця 3. Динаміка вмісту ІЛ-18 у сироватці крові хворих на еритемну форму Лайм-бореліозу, поєднану з ураженнями інших органів і систем, при використанні різних схем лікування (Me (Lq; Uq))

\begin{tabular}{|c|c|c|}
\hline Група пацієнтів & До лікування & На 30-ий день після лікування \\
\hline 1 -а $(n=53)$ & $211,45(163,25 ; 264,15)$ & $190,65(158,80 ; 220,70)$ \\
\hline 2-а $(n=60)$ & $236,35(174,60 ; 314,40)$ & $168,70(134,40 ; 221,10)^{*}$ \\
\hline
\end{tabular}

Примітка. * - різниця достовірна з показниками до лікування $(p<0,05)$.

Таким чином, застосування настою з листків стевії медоносної у хворих з еритемною формою ХЛ сприяло достовірному зниженню вмісту прозапального ІЛ-18 у сироватці крові, на відміну від осіб, які не отримували фітонастій.

До лікування у пацієнтів обох груп концентра- ція протизапального ІЛ-10 у сироватці крові достовірно не відрізнялась і знаходилась у межах норми (табл. 4). Після лікування у хворих обох груп вміст цього цитокіну суттєво зріс, порівняно з показниками на початку лікування $(p<0,05)$, хоча також залишався в межах референтних величин

Таблиця 4. Динаміка вмісту ІЛ-10 у сироватці крові хворих на еритемну форму Лайм-борелізу, поєднану з ураженнями інших органів і систем, при використанні різних схем лікування (Me (Lq; Uq))

\begin{tabular}{|c|c|c|}
\hline Група пацієнтів & До лікування & На 30-ий день після лікування \\
\hline 1-а $(\mathrm{n}=53)$ & $4,10(3,10 ; 10,40)$ & $13,20(9,00 ; 18,70)^{*}$ \\
\hline 2-а $(\mathrm{n}=60)$ & $3,85(1,25 ; 17,08)$ & $18,55(12,40 ; 26,00)^{*}, * *$ \\
\hline
\end{tabular}

Примітки: * - різниця достовірна порівняно з показниками до лікування ( $<<0,05)$,

** - різниця достовірна порівняно з показниками 1-ї групи $(p<0,05)$. 
Огляди літератури, оригінальні дослідження, погляд на проблему, випадок з практики, короткі повідомлення ( $<<0,05)$. У той же час в осі6, які отримували комплексне лікування з використанням ще й настою з листків стевії медоносної, відзначено значне збільшення рівня ІЛ-10 у динаміці, порівняно 3 тими, хто не вживав цього фітонастою (р<0,05).

Отже, концентрація протизапального ІЛ-10 у сироватці крові була значно вищою в осіб, яких лікували з використанням настою з листків стевії медоносної.

У хворих на еритемну форму ХЛ швидкість зникнення клінічних проявів недуги, які виражали у балах, залежала від схеми терапії. Застосування настою з листків стевії медоносної у комплексному лікуванні пацієнтів сприяла їх швидшому клінічному одужанню. Також скорочувалась тривалість призначення антибіотика доксицикліну гідрохлориду, вживання якого може призвести до виникнення побічних явищ. На нашу думку, за рахунок комплексу БАР стевії медоносної, які мають виражену антиоксидантну і протизапальну дію [17], вдалося пришвидшити зникнення проявів ЛБ.

Згідно з даними літератури, прозапальний цитокін ІЛ-18, який належить до родини ІЛ-1, продукується багатьма типами клітин і має досить широкий спектр біологічних ефектів [21]. Він порушує баланс цитокінів у бік клітинного імунітету, стимулює продукцію IFN- $\gamma$, TNF- $\alpha$, гранулоцитарно-макрофагального колонієстимулюючого фактора, ІЛ-2 і деяких інших цитокінів, молекул адгезії, що беруть участь у механізмах клітинної міграції. Це має значення як при формуванні імунної відповіді, так і в патогенезі низки захворювань, у тому числі й ХЛ. Призначення настою з листків стевії медоносної у комплексному лікуванні хворих на еритемну форму ХЛ сприяло достовірному зниженню вмісту прозапального ІЛ-18 у сироватці крові.

Протизапальний ІЛ-10, що виробляється макрофагами і Th2, пригнічує гіперчутливу відповідь сповільненого типу Th1 клітин, що опосередковує підвищення вироблення антитіл класу Ig G [22]. Цей цитокін певним чином сприяє створенню передумов для переходу інфекційного процесу в стадію обмеження запалення і швидшому розрішенню патологічного процесу. Підвищення вмісту протизапального цитокіну ІЛ-10 у хворих на ME у динаміці терапії може розглядатися як

протективна реакція для пригнічення активності прозапальних цитокінів. Менший рівень ІЛ-10 у сироватці крові хворих, яких лікували триваліший час доксицикліну гідрохлоридом, може свідчити про наявність взаємозв'язків між його рівнем і тяжкістю перебігу недуги і підтверджувати патогенетичний зв'язок між низькою концентрацією ІЛ-10 і довшим збереженням патологічних проявів при ЛБ. Концентрація протизапального ІЛ-10 у сироватці крові була значно вищою в осіб, яких лікували з використанням настою Стевії медоносної. Отримані результати дають підстави вважати, що фенольні сполуки листків стевії медоносної виявляють протизапальну активність, тому у хворих, які отримали комплексне лікування, значно зменшувався рівень прозапального цитокіну ІЛ-18, у той же час рівень протизапального цитокіну ІЛ-10 на 30-ий день після закінчення лікування зростав у 3,5 раза. Зазначене вище, мабуть, забезпечує ранню запальну реакцію, формування клітинного і гуморального імунітенту, що сприяє елімінації борелій та одужанню хворого.

Висновки. 1. Застосування в комплексному лікуванні хворих на еритемну форму Лайм-бореліозу доксицикліну гідрохлориду разом із насто$€ м$ із листків стевії медоносної сприяє суттєво швидшому зникненню клінічних проявив недуги, а також скороченню термінів призначення доксицикліну гідрохлориду і зменшує ймовірність виникнення побічних ефектів від цього препарату.

2. Комплексна терапія пацієнтів з використанням настою із листків стевії медоносної зумовлює зменшення вмісту в сироватці крові прозапального ІЛ-18 і підвищення концентрації протизапального ІЛ-10, що забезпечує ранню запальну реакцію, формування клітинного і гуморального імунітенту, що сприяє елімінації борелій та одужанню хворого.

3. У комплексне лікування хворих на еритемну форму хвороби Лайма доцільно включати настій із листків стевії медоносної.

Перспективи подальших досліджень. Продовжити вивчати застосування настою із листків стевії медоносної як протимікробного і протизапального засобу при інших інфекційних захворюваннях.

\section{ЛІТЕРАТУРА}

1. Effectiveness of stevia rebaudiana whole leaf extract against the various morphological forms of Borrelia burgdorferi in vitro / P. Theophilus, M. Victoria, K. Socarras [et al.] // European Journal of Microbiology and Immunology. -2015. - Vol. 5, No 4. - P. 268-280.

2. Sjögren's syndrome and lymphadenopathy unraveling the diagnosis of Lyme disease / S. Smiyan, I. Galaychuk, I. Zhulkevych [et al.] // Reumatologia. -2019. - Vol. 57 (1). - P. 59-62.

3. Куляс С. М. Сучасний погляд на особливості специфічної діагностики, лікування та профілактики Лайм- 
Огляди літератури, оригінальні дослідження, погляд на проблему, випадок з практики, короткі повідомлення бореліозу / С. М. Куляс // Biomedical and Biosocial Anthropology. - 2013. - № 20. - C. 254-260.

4. Скрипченко, Н. В. Современные представления o патогенезе иксодовых клещевых боррелиозов / Н. В. Скрипченко, А. А. Балинова // Журнал инфектологии. - 2012. - Т. 4, № 2. - С. 5-14.

5. Миноранская, Н. С. Значение иммунного статуса для прогноза хронизации боррелиозной инфекции / Н. С. Миноранская, А. Н. Усков, П. В. Сарап // Журнал инфектологии. - 2014. - Т. 6, № 1. - С. 35-40.

6. Бореліозна лімфаденопатія у практиці онколога (клінічні спостереження) / І. Й. Галайчук, І.В.Жулкевич, С. І. Сміян [та ін.] // Онкологія. - 2019. - Т. 21, № 3. C. 250-253.

7. Naj X. Actin-dependent regulation of borrelia burgdorferi phagocytosis by macrophages / X. Naj, S. Linder // Curr. Top Microbiol. Immunol. - 2016.

8. Лайм-бореліоз. Діагностичні критерії, лікування і профілактика: метод. рекомендації / уклад. : М. А. Андрейчин, В. С. Копча, М. І. Шкільна, С. О. Никитюк. - Тернопіль : ТДМУ, 2019. - 52 с.

9. Nelson M. L. The history of the tetracyclines / M. L. Nelson, S. B. Levy // Ann. NY. Acad. Sci. - 2011. No. 1241. - P. 17-32.

10. Lyme borreliosis / G. Stanek, G. P. Wormser, J. Gray, F. Strle // Lancet. -2012. - No. 379. - P. 461-473.

11. Goc A. Cooperation of doxycycline with phytochemicals and micronutrients against active and persistent forms of Borrelia sp / A. Goc, A. Niedzwiecki, M. Rath // International Journal of Biological Sciences. -2016. - Vol. 12 (9). - P. 1093-1103.

12. Попова Н. В. Лекарственные растения мировой флоры / Н. В. Попова, В. И. Литвиненко, А. С. Куцанян. Харьков : Дика плюс, 2016. - С. 405.

13. Фитохимический анализ стевии и стахиса на содержание биологически активных веществ / Б. А. Сарсебаев, В. К. Мурсалиева, Н. А. Султанова [и др.] // Вестник КазНУ. Серия химическая. - 2012. - № 1 (65). С. 370-373.

\section{REFERENCES}

1. Theophilus, P.A., Victoria, M.J., Socarras, K.M., Filush, K.R., Gupta, K., Luecke, D.F., \& Sapi, E. (2015). Effectiveness of stevia rebaudiana whole leaf extract against the various morphological forms of Borrelia burgdorferi in vitro. European Journal of Microbiology and Immunology, 5, 4, 268-280.

2. Smiyan, S., Galaychuk, I., Zhulkevych, I., Nykolyuk, V., Komorovsky, R., Gusak, S., \& Bilozetsky I. (2019). Sjögren's syndrome and lymphadenopathy unraveling the diagnosis of Lyme diseas. Reumatologia, 57 (1), 59-62. Retrieved from: https://doi.org/10.5114/reum.2019.83242.

3. Kulias, S.M. Suchasnyi pohliad na osoblyvosti spetsyfichnoi diahnostyky, likuvannia ta profilaktyky Laimboreliozu [A modern look at the features of specific diagnosis, treatment and prevention of Lyme borreliosis]. Biomedical and Biosocial Anthropology, 20, 254-260 [in Ukrainian].

4. Skrypchenko, N.V., \& Balynova, A.A. (2012). Sovremennye predstavlenyia o patogeneze yksodovukh klesh-

14. Phytochemical streening and comparative antimicrobial potential of different extract of Stevia rebaudiana Bertoni leaves / A. B. Siddique, S. M. M. Rahman, M. A. Hossain [et. al.] // Asian. Pacific J. Trop. Dis. -2014. - Vol. 4 (4). P. 275-280.

15. Puri M. Antibacterial activity of stevioside to-wards food-dorne pathogenic bacteria / M. Puri, D. Sharma // Eng. Life Sci. -2011. - No. 11. - P. 326-329.

16. Семенова Е. Ф. Скрининг антимикробной активности жидких экстрактов стевии Ребо (Stevia rebaudiana Bertoni) / Е. Ф. Семенова, А. С. Веденеева, Т. П. Жужжалова // Вестник ВГУ. Серия: Химия. Биология. Фармация. 2010. - № 1. - С. 121-126.

17. Козачок С. Визначення фенольних сполук у стевії листках / С. Козачок, Н. Гудзь, Т. Атаманчук // «XVIII Міжнародний медичний конгрес студентів та молодих вчених» : мат. конгресу Тернопіль, 28-30 квітня 2014 р. Тернопіль: Укрмедкнига, 2014. - С. 262.

18. HPLC analysis of phenolic compounds from Stevia rabaudiana Bertoni leaves / S. Marchyshyn, N. Hudz, I. Dakhym [et. al.] // The Pharma Innovation Journal. - 2018. Vol. 7 (3). - P. 515-517.

19. Stevia rebaudiana Bert. leaf extracts as a multifunctional source of natural antioxidants / K. Gaweł-Bęben, T. Bujak, Z. Nizioł-tukaszewska [et. al.] // Molecules. 2015. - No. 20. - P. 5468-5486.

20. The role of interleukin-1 and interleukin-18 in proinflammatory and anti-viral responses to rhinovirus in primary bronchial epithelial cells / S. C. Piper, J. Ferguson, L. Kay [et. al.] // PLoS One. -2013. -Vol. 8, № 5. -P. e63365.

21. Абатуров А. Е. Участие интерлейкинового сімейства 1 в развитии воспалительной реакции при инфекционном процес се. 3. Роль IL-1F4 (IL-18) / А. Е. Абатуров, А. П. Волосовець, Е. І. Юлиш // Теоретична медицина. - 2014. - Т. 4, № 55. - С. 135-138.

22. Интерлейкин-1, интерлейкин-10 в регуляции воспалительного процесса / С. Н. Серебренникова, И. Ж. Семинский, Н. В. Семенов, Е. В. Гузовская // Сибирский медицинский журнал. -2012. - № 8. - С. 5-8.

chevykh borrelyozov. Zhurnal infektologii - Infectology Journal, 4, 2, 5-14 [in Russian].

5. Mynoranskaya, N.S., Uskov, A.N., \& Sarap, P.V. (2014). Znachenye immunnogo statusa dlya prognoza khronyzatsii borrelyoznoy infektsii [The importance of immune status for predicting the chronicity of borreliosis infection]. Zhurnal infektologii - Infectology Journal, 6, 1, 35-40 [in Russian].

6. Naj, X., \& Linder, S. (2016). Actin-dependent regulation of Borrelia burgdorferi phagocytosis by macrophages. Curr. Top. Microbiol. Immunol.

7. Galaychuk, I.Y., Zhulkevych, I.V., Smiyan, S.I., Nykolyuk, V.D., \& Komorovsky, R.R. (2019). Boreliozna limfadenopatiya u praktytsi onkoloha (klinichni sposterezhennia) [Borrelious lymphadenopathy in oncology practice (clinical observations)]. Onkolohiia - Oncology, 21, 3, 250-253. DOI: 10.32471/oncology.2663-7928.t-21-3-2019-7896. URL: https://www.oncology.kiev.ua/article/7896/boreliozna-limfadenopatiya-u-praktici-onkologa-klinichnisposterezhennya [in Ukrainian]. 
Огляди літератури, оригінальні дослідження, погляд на проблему, випадок з практики, короткі повідомлення

8. Andreychyn, M.A., Kopcha, V.S., Shkilna, M.I., \& Nykytyuk, S.O. (compilers) (2019). Laim-borelioz. Diahnostychni kryterii, likuvannia i profilaktyka: metod. rekomendatsii [Diagnostic criteria, treatment and prevention: a method. Recommendations]. Ternopil: TDMU. [in Ukrainian].

9. Nelson, M.L., \& Levy, S.B. (2011). The history of the tetracyclines. AnnNYAcadSci., 1241, 17-32.

10. Stanek, G., Wormser, G.P., Gray, J., \& Strle, F. (2012). Lyme borreliosis. Lancet, 379, 461-473.

11. Goc, A., Niedzwiecki, A., \& Rath, M. Cooperation of doxycycline with phytoch micals and micronutrients against active and persistent forms of Borrelia sp. International Journal of Biological Sciences, 12 (9), 1093-1103.

12. Popova, N.V., Lytvynenko, V.Y., \& Kutsanian, A.S. (2016). Lekarstvennyye rasteniya mirovoy flory [Medicinal plants of the world flora]. Kharkov: Dika plius [in Russian].

13. Sarsenbayev, B.A., Mursaliyeva, V.K., Sultanova, N.A., Mamonov, L.K., \& Usenbekov, B.N. (2012). Fitokhimicheskiy analiz stevii i stakhisa na soderzhaniye biologicheski aktivnykh veshchestv [Phytochemical analysis of stevia and stachis for the content of biologically active substances]. Vestnik Kaz. NU. Seriya khimicheskaya - Bulletin of the Kazan National University. Chemical Series, 1 (65), 370-373 [in Russian].

14. Siddique, A.B., Rahman, S.M.M., Hossain, M.A., Hossain, M.A., \& Rashid, M.A. (2014). Phytochemical screening and comparative antimicrobial potential of different extractof Stevia rebaudiana Bertonileaves. Asian. Pacific J. Trop. Dis., 4 (4), 275-280.

15. Puri, M., \& Sharma, D. (2011). Antibacterial activity of stevio sideto-wards food-dornepathogenic bacteria. Eng. Life Sci., 11, 326-329.

16. Semenova, E.F., Vedeneeva, A.S., \& Zhuzhzhalova, T.P. (2010). Skrining antimikrobnoy aktivnosti zhidkikh ekstraktov stevii Rebo (Stevia rebaudiana Bertoni) [Screening of the antimicrobial activity of liquid extracts of Stevia Rebo (Stevia rebaudiana Bertoni)]. Vestnik VGU. Seriya: Khi- miya. Biologiya. Farmatsiya - Bulletin of the Voronezh State University. Series: Chemistry. Biology. Pharmacy, 1, 121-126 [in Russian].

17. Kozachok, S., Hudz, N., \& Atamanchuk, T. (2014). Vyznachennia fenolnykh spoluk u stevii lystkakh [Determination of phenolic compounds in stevia leaf]. Proceedings of the Congress: "XVIII Mizhnarodnyy medychnyy konhres studentiv ta molodykh vchenykh" - "XVIIIth International Medical Congress of Students and Young Scientists". 262 p. Ternopil: "Ukrmedknyha" [in Ukrainian].

18. Marchyshyn, S., Hudz, N., Dakhym, I., Husak, L., \& Demydyak, O. (2018). HPL Canalysis of phenoli ccompounds from Stevia rabaudiana Bertonileaves. The Pharma Innovation Journal, 7 (3), 515-517.

19. Gaweł-Bęben, K., Bujak, T., Nizioł-Łukaszewska, Z., Antosiewicz, B., Jakubczyk, A., Karaś, M., \& Rybczyńska, K. (2015). Stevia rebaudiana Bert. Leaf Extracts asa Multifunctional Source of Natural Antioxidants. Molecules, 20, 54685486.

20. Piper, S.C., Ferguson, J., Kay, L., Parker, L.C., Sabroe, I., Sleeman, M.A., ..., \& Finch, D.K. (2013). The role of interleukin-1 and interleukin-18 in pro-inflammatory and antiviral responses to rhinovirus sinprimary bronchial epithelial cells. PLoSOne, 8, 5, e63365.

21. Abaturov, A.E., Volosovets, A.P., \& Yulysh, E.I. (2014). Uchastiye interleykinovogo simeystva $1 \mathrm{v}$ razvitii vospalitelnoy reaktsii pri infektsionnom protsesse. 3. Rol IL1F4 (IL-18) [Participation of interleukin family 1 in the development of the inflammatory reaction in the infectious process. 3. The role of IL-1F4 (IL-18)]. Teoretychna medytsynaTheoretical Medicine, 4, 55, 135-138 [in Russian].

22. Serebrennikova, S.N., Seminskiy, I.Zh., Semenov, N.V., \& Guzovskaya, Ye.V. (2012). Interleykin-1, interleykin-10 v regulyatsii vospalitelnogo protsessa [Interleukin-1, interleukin-10 in the regulation of the inflammatory process]. Sybyrskiy medytsynskiy zhurnal - Siberian Medical Journal, 8, 5-8 [in Russian].

\title{
ПОВЫШЕНИЕ ЭФФЕКТИВНОСТИ КОМПЛЕКСНОГО ЛЕЧЕНИЯ БОЛЬНЫХ ЛАЙМ-БОРРЕЛИОЗОМ С ИСПОЛЬЗОВАНИЕМ СТЕВИИ МЕДОНОСНОЙ
}

\author{
ОМ. И. Шкильна, С. М. Марчишин, М. А. Андрейчин, О. Л. Ивахив, \\ М. М. Корда, С. И. Запорожан, И. Н. Клищ \\ Тернопольский национальный медцинский университет имени И. Я. Горбачевского МОз Украины
}

РЕЗЮМЕ. Цель - усовершентствование комплексного лечения больных Лайм-боррелиозом с помощью сочетанного применения доксициклина гидрохлорида и настоя листьев стевии медоносной.

Материал и методы. Под наблюдением было 113 больных с эритемной формой Лайм-боррелиоза; мужчин - 49 (43,4 \%), женщин - 64 (56,6 \%). Средний возраст обследованных составил $(42,65 \pm 13,91)$ года. Апробированы две схемы комплексного лечения больных. Пациенты 1-й группы (53) получали доксициклина гидрохлорид по 200 мг в день (в 2 приема по 100 мг) в течение 21 дня, карсил и хилак; больные 2-й группы (60) принимали первую схему в течение 14 дней, а дальше - только настой из листьев стевии медоносоной (Stevia rebaudiana (Bertoni) Hemsley) по 1 стакану два раза в день, в течение 14 дней.

Результаты. У больных, которые в комплексном лечении получали докциклина гидрохлорид вместе с настоем листьев стевии медоносной, на 30-ый день после окончания лечения отмечено достоверное уменьшение степени тяжести болезни, по сравнению с пациентами другой группы. Комплексная терапия больных Лаймборрелиозом с использованием с настоя листьев стевии медоносной обусловливает уменьшение содержания в сыворотке крови провоспалительного ИЛ-18 и повышение концентрации противовоспалительного ИЛ-10.

Выводы. Комплексное лечение больных эритемной формой Лайм-боррелиоза с использованием настоя из листьев стевии медоносной способствует существенно более быстрому исчезновению клинических проявлений 
Огляди літератури, оригінальні дослідження, погляд на проблему, випадок з практики, короткі повідомлення болезни, сокращению длительности назначения доксициклина гидрохлорида, а также уменьшает вероятность возникновения побочных эффектов этого препарата. Применение в комплексном лечении больных эритемной формой болезни Лайма доксициклина гидрохлорида вместе с настоем из листьев стевии медоносной обеспечивает раннюю противовоспалительную реакцию, формирование клеточного и гуморального иммунитета, что способствует элиминации боррелий и выздоровлению больного.

КЛЮчЕВЫЕ СЛОВА: Лайм-боррелиоз; доксициклина гидрохлорид; стевия медоносная; лечение.

\title{
INCREASING EFFICIENCY OF COMPLEX TREATMENT OF PATIENTS WITH LYME BORRELIOSIS USING STEVIA REBAUDIANA
}

\author{
@M. I. Shkilna, S. M. Marchyshyn, M. A. Andreychyn, O. L. Ivakhiv, \\ M. M. Korda, S. Y. Zaporozhan, I. M. Klishch

\section{Horbachevsky Ternopil National Medical University}

SUMMARY. The aim - improvement of the complex treatment of patients with Lyme borreliosis, using of combined application of doxycycline hydrochloride and infusion of Stevia rebaudiana leaves.

Material and Methods. The tested group consisted of 113 patients with erythematous form of Lyme borreliosis; men -49 (43.4\%), women -64 (56.6\%). The average age of the examined persons was (42.65 \pm 13.91$)$ years. Two schemes of complex treatment of patients were tested. Patients of group 1 (53) received doxyxycline hydrochloride $200 \mathrm{mg}$ per day (in 2 doses of $100 \mathrm{mg}$ ) for 21 days, Carsil and Hylak; patients of group 2 (60) took the first regimen for 14 days, and then only infusion from the leaves of Stevia rebaudiana, 1 glass twice a day, for 14 days.

Results. A significant decrease of the severity of the disease was noted on the 30-th day after treatment in patients, who received doxyxycline hydrochloride together with infusion from the leaves of Stevia rebaudiana in a complex treatment, compared with patients of another group.

Complex therapy of patients with Lyme borreliosis, using infusion from the leaves of Stevia rebaudiana, causes a decrease of the content of pro-inflammatory IL-18 and increase of anti-inflammatory IL-10 in blood serum.

Conclusions. The complex treatment of patients with erythematous form of Lyme borreliosis, using an infusion from the leaves of Stevia rebaudiana contributes to a significantly faster disappearance of the clinical manifestations of the disease, reduction duration of the doxyxycline hydrochloride, and reduces the bedside effects of this drug. The use of doxyxycline hydrochloride in combination with infusion from the leaves of Stevia rebaudiana in treatment of the patients with erythematous form of Lyme borreliosis contributes to a significantly faster provides an early antiinflammatory response, the formation of cellular and humoral immunity, which contributes to the alimination of Borrelia and patient's recovery.

KEY WORDS: Lyme borreliosis; doxyxycline hydrochloride; Stevia rebaudiana; treatment.

Отримано 12.02.2020 